International Journal of Business Management and Economic Review

Vol. 4, No. 06; 2021

ISSN: 2581-4664

\title{
THE EFFECT OF EFFECTIVENESS OF ACCOUNTING INFORMATION SYSTEM, COMPLIANCE WITH LAW AND ORGANIZATIONAL COMMITMENT ON THE ACCOUNTABILITY PERFORMANCE OF GOVERNMENT INSTITUTIONS
}

(Study on District's Governmental Working Unit (SKPK) of Aceh Singkil Regency, Province of Aceh, Indonesia)

\author{
Mulianto, Yossi Diantimala and Nuraini \\ Magister Accountancy Program, Faculty of Economics and Business, Universitas Syiah Kuala, Banda Aceh, \\ Indonesia \\ http://doi.org/10.35409/IJBMER.2021.3332
}

\begin{abstract}
This study aims to examine the effect of the effectiveness of accounting information system, compliance with law and organizational commitment both simultaneously and partially on the accountability performance of government institution at SKPK of Aceh Singkil Regency. The population in this study is all SKPKs which includes offices, agencies and agencies in Aceh Singkil. Meanwhile, the respondents were the Head of SKPK, the Head of the Sub Division of Finance, and the Head of the Sub Division of the Program with a total of 138 respondents. Sources of data in this study employed primary data of which obtained through the distribution questionnaires from respondents. While the research data collection technique was carried out by using documentation techniques, the analytical method used is Multiple Linear Regression Analysis. The results showed that the effectiveness of the accounting information system, compliance with law and organizational commitment have both simultaneous and partial influences on the accountability performance of government institutions at SKPK Aceh Singkil Regency.
\end{abstract}

Keyword: Effectiveness of Accounting Information System, Compliance with Law, Organizational Commitment, Accountability Performance of Government Institutions.

\section{INTRODUCTION}

Performance accountability is a manifestation of the obligation to account for the success or failure of the organization's mission in achieving the goals and objectives that have been set through an accountability medium which is carried out periodically (Pusdiklatwas BPKP, 2011:2). As a general principle,the accountability of state administration determines that every activity and the final result of state administration activities must be accountable to the public as the holder of the highest state sovereignty.

In order to realize a figure of state governance that is clean and free from Corruption, Collusion and Nepotism (KKN), the government issued Law no. 28 of 1999 and as a follow-up, the government issued Presidential Instruction Number 7 of 1999 concerning Accountability for Performance of Government Agencies. In order for each Government Agency to be Accountable, this Presidential Instruction considers the need for performance accountability 


\section{International Journal of Business Management and Economic Review}

Vol. 4, No. 06; 2021

ISSN: 2581-4664

reporting and to implement it, a Government Agency Performance Accountability System has been developed (Inpres No. 7 of 1999).

The essence of these regulations is that government agencies are required to be accountable for the implementation of their main duties and functions as well as the authority to manage their resources by compiling LAKIP (Government Agencies Performance Accountability Report). In the framework of implementing Law no. 17 of 2003 concerning State Finance and its various implementing regulations, financial reporting and performance within government agencies is also an important part of improving the accountability and performance of the government bureaucracy (PP No. 8 of 2006).

With the existence of LAKIP, it is hoped that it can motivate the bearers of the responsibility to exert high skills and discipline to achieve the goals they have set. The making of this report is by no means just a matter of government administration, but more than that it is a form of accountability that must be carried out by bearers of responsibility towards the public.

Problems related to agency performance accountability occur not only in the central government but also in regional governments, such as in Aceh. Based on the Report on the Evaluation Results of the Performance Accountability System for District/City Governments in Aceh in 2017, 6 (six) districts/cities, namely West Aceh District, Aceh Singkil, Bener Meriah, North Aceh, Aceh Jaya, and Banda Aceh City received the value of the CC rating or category is Adequate. For Aceh Singkil District, the problem of accountability for the performance of government agencies has obstacles including (LAKIP Aceh Singkil Regency, 2019): Planning aspects, implementation functions, low understanding of ASN in implementing ASN Performance Accountability. The function of the Performance Agreement between superiors and subordinates is not used as a basis for providing rewards and punishments. The Supervision function is still weak on the implementation of performance accountability

because it is affected by the quality and quantity of auditors at the District

Inspectorate.

Based on the description of the problem, it can be assessed that the performance accountability of the Aceh Singkil District Government agencies is not yet fully good. Therefore, further discussion is needed in the form of studies related to the performance accountability of government agencies. Until now, there have been many previous studies that examined and discussed the performance accountability of government agencies such as; Irawati and Agesta (2019), Zulfiandri (2017), Putri (2015), Wardhana, Rasmini and Astika (2015), Friska (2015), Syafariani and Feryani (2014), Darwanis and Chairunnisa (2013), Riantiarno and Azlina (2011) ), Zeyn (2011).

First, the effectiveness of the accounting information system affects the performance accountability of government agencies. The role of information systems on organizational progress is beyond doubt. With the support of a good information system, an organization will have various conveniences. Accounting information system refers to PP. 58 of 2005 and Permendagri No.

13 of 2006 and Permendagri No. 59 of 2007. The benefits of implementing an Accounting Information System (SIA) based on Government Accounting Standards (SAP) are aimed at increasing the accountability and reliability of government financial managers through the 


\section{International Journal of Business Management and Economic Review}

Vol. 4, No. 06; 2021

ISSN: 2581-4664

preparation and development of SAP. SIA is also an effective tool for creating public accountability (Mardiasmo, 2006).

Second, compliance with laws affects the accountability of the performance of government agencies. Compliance with laws is an important element that is directly related to the accountability of the performance of government agencies. With this, it is hoped that the resulting accountability reports will be accurate and appropriate in fulfilling obligations to the central government and the need for public information. However, local governments tend not to implement the laws in question (Putri, 2015).

Third, organizational commitment affects the performance accountability of government agencies. Organizational commitment can be a psychological tool in running the organization to achieve the expected goals (Darma, 2004). Organizational commitment itself is an ability to be responsible for the work entrusted to someone in the organization. With the growing commitment of employees to the organization, performance accountability will also increase. The reason for choosing Aceh Singkil Regency as the research location was that there were still problems related to the accountability of the performance of agencies in that area. Aceh Singkil is also still included in the $\mathrm{CC}$ value rating or in the quite adequate category based on the SAKIP evaluation report by PANRB. Of course, this is the main attraction for researchers to conduct further research related to the factors that affect the accountability of agency performance. Based on the previous description, the purpose of this study was determined, namely to examine the effect of the

effectiveness of the accounting information system, compliance with legislation and organizational commitment both jointly and separately on the performance accountability of government agencies at SKPK Aceh Singkil Regency.

\section{LITERATURE REVIEW}

\section{Accountability Performance of Government Institutions}

Decree of the Head of LAN No.239 / IX / 6/8/2003 concerning Guidelines for

the Compilation of Performance Accountability Reporting for Government Agencies, explains that the performance accountability of government agencies is a manifestation of the obligation of a government agency to be accountable for the success and failure of implementing the organization's mission in achieving the goals and objectives that have been determined through a periodic accountability system. Mardiasmo (2004:26) defines accountability as "the obligation of the trustee (agent) to give accountability, and disclose all activities and activities that are their responsibility to the principal who has the right and authority to hold this accountable". Accountability can also be interpreted as the responsibility of the party who is mandated to be ordered by those who give the mandate (Krina, 2003:

3). Accountability can also be defined as a form of obligation to account for the success or failure of the organization's mission in achieving the goals and objectives that have been previously set, through a periodic accountability medium (Stanbury, 2003:12).

\section{Effectiveness of Accounting Information Systems}

The system is an entity consisting of two or more components that interact 


\section{International Journal of Business Management and Economic Review}

Vol. 4, No. 06; 2021

ISSN: 2581-4664

with each other to achieve goals. The system that is relevant to accounting tasks is a computer based system, which means the integration of equipment, programs, data and procedures to carry out one task on a computer. The success of a system requires defined goals. A system with a specific goal will accomplish more for an organization, than a system without goals, few goals, or ambitious goals (Mukhtar,

2002: 2) . Information is useful data that is processed so that it can be used as a basis for making the right decisions (Bodnar and Hopwood, 2006:1). The same thing was expressed by Parjanti, Hendra and Nurlela (2014) who stated that information is knowledge from the results of processing related data into a conclusion. Some data can be stated as information if the data can be used to draw a conclusion. Furthermore, what is meant by Accounting Information Systems (AIS) according to Bodnar and Hopwood (2006) is a collection of resources such as people and equipment, which are designed to convert financial data and other data into useful information. This information is communicated to various decision makers. SIA makes these changes happen, either manually or with the help of computers. Effectiveness is a measure that provides an idea of how far the target can be achieved. Generally, effectiveness is often associated with efficiency in achieving company goals, goals or objectives that have been achieved in accordance with the plan can be said to be effective, but not necessarily efficient (Sedarmayanti, 2007).

\section{Compliance with Laws}

In terms of the formation of government accounting in accordance with the characteristics and aiming to fulfill adequate state financial accountability, the United Nations (UN) has issued a guideline for government accounting (a manual for government accounting ) that is able to meet the requirements of laws and regulations.

Rasjidi (2004) defines statutory regulations as state regulations, which at the central and regional levels are formed based on statutory authority, both attributable and delegate in nature. The legal system adopted in the public sector accounting system is the civil law system, where every rule related to public sector accounting is contained in the form of laws and regulations. Looking further, it is necessary to understand theoretical material in the framework of making laws and regulations. Stuffen theories argues that a legal system is a hierarchy of laws where another higher legal provision is a Grundnorm or hypothetical basic norm. Legislation is a written regulation formed by a State institution or an authorized official and has binding force (Putri, 2015). Compliance with laws and regulations is an important factor related to the accountability of the performance of government agencies. With this, it is hoped that the resulting accountability reports will be accurate and appropriate in order to fulfill obligations to the central government and public information needs.

\section{Organizational Commitment}

According to Griffin (2004:15) organizational commitment is "an attitude that reflects the degree to which an individual knows and is tied to the organization". Robbins (2008) defines organizational commitment as "a level of confidence in an employee siding with a particular organization whose purpose is to maintain and maintain membership in that organization". Furthermore, Zainuddin (2002) states "organizational commitment as a relative strength of the individual in identifying his involvement in the organization". Mathis and Jackson 


\section{International Journal of Business Management and Economic Review}

Vol. 4, No. 06; 2021

ISSN: 2581-4664

(2000) state that "organizational commitment is a relative strength of the individual in identifying his involvement in the organization". Furthermore, according to Bashaw and Grant (1994) defines organizational commitment as "the desire of employees to maintain their membership in the organization and are willing to make high efforts for the achievement of organizational goals".

\section{RESEARCH METHOD}

This research is a census research because all members of the population are made respondents. The population of this research is institutions/institutions, namely SKPK which includes offices, services and agencies in Aceh Singkil. Each SKPK will be assigned 3 (three) people as respondents, namely; Head of SKPK, Head of Sub Division of Finance, and Head of Sub Division of Programs, so that the total respondents were 138 people (46 SKPK x 3 respondents). Sources of data in this study using primary data, namely the acquisition of questionnaires from respondents. While the research data collection technique is done by using documentation technique. The analytical method used is Multiple Linear Regression Analysis.

Operationalization of variables in this study can be described as follows;

a. Accountability Performance of Government Institutions (Y), Government agency performance accountability is a manifestation of the obligation of a government agency to be accountable for the success and failure of the organization's mission to achieve the goals and objectives that have been set through a periodic accountability system (Decree of the Head of LAN No.239/IX/6/8/2003). Indicators and measuring tools for the accountability of the performance of government agencies based on Haspiarti's (2012) research which includes; Achievement of performance and clarity of budget targets, Determination of vision and mission and performance indicators, financial analysis and program

reports, checking of programs and implementation of activities, programs according to community needs and completion of LAKIP. The scale used is an interval scale in the form of a 5-point Likert scale.

b. Effectiveness of Accounting Information Systems (X1), Effectiveness of AIS according to Sierrawati and Damayanthi (2012) is a measure that provides an overview of the extent to which targets can be achieved from a set of resources that are arranged to collect, process and store electronic data, then convert it into information which is useful and provides the required formal reports properly. Indicators of the effectiveness of accounting information systems based on Cushing (2009: 990) which include; Useful, Economy, Reabilitty, Customer Service, Capacity, Simplicity, and Flexibility. The scale used is an interval scale in the form of a 5-point Likert scale. c. Compliance with Laws (X2), compliance with laws is a written regulation established by a State institution or an authorized official and has binding power (Putri, 2015). The indicators used based on Lumenta, Morasa, and Mawikere (2016) include: Compliance with laws and regulations in the implementation of public accountability, Imposing sanctions for parties who do not comply with regulations, Compatibility of the implementation of AKIP with Presidential Instruction No. 7 of 1999, financial management in accordance with PP. 58 of 2005, Guidelines for financial reporting and agency performance in accordance with PP. 8 of 2006, Guidelines for making financial reports in accordance with PP. 71 of 2010, Guidelines for regional financial management in accordance with Permendagri No. 21 of 2011. The scale used is an interval scale in the form of a 


\section{International Journal of Business Management and Economic Review}

Vol. 4, No. 06; 2021

ISSN: 2581-4664

5-point Likert scale.

d. Organizational Commitment (X3), organizational commitment is a level of confidence in an employee siding with a particular organization whose purpose is to maintain and maintain its membership in that organization (Robbins (2008). Indicators used based on Zainuddin (2002) include; Affective commitment, Commitment normative, continuous commitment. The scale used is the interval scale in the form of a 5-point Likert scale.

\section{RESULTS AND DISCUSSIONS}

\section{Results}

\section{Descriptive Analysis}

Descriptive analysis for each variable in this study was obtained based on a questionnaire that has been filled in by respondents to the variables, namely the accountability of the performance of government agencies (Y), the effectiveness of the accounting information system (X1), compliance with legislation (X2), and organizational commitment (X3). The following is the descriptive statistical value of each research variable can be seen on Table 1 as follow.

\section{Tabel 1 Descriptive Statistic}

\begin{tabular}{|l|c|c|c|c|}
\hline & Average & Standard & Minimum & Maximum \\
\hline $\begin{array}{l}\text { Accountability } \\
\text { Performance of } \\
\text { Government Institutions }\end{array}$ & 4,35 & 0,277 & 3,47 & 4,93 \\
\hline $\begin{array}{l}\text { Effectiveness of } \\
\text { Accounting Information } \\
\text { Systems }\end{array}$ & 4,20 & 0,37 & 3,24 & 5,00 \\
\hline Compliance with Laws & 4,31 & 0,29 & 3,71 & 5,00 \\
\hline $\begin{array}{l}\text { Organizational } \\
\text { Commitment }\end{array}$ & 4,02 & 0,51 & 2,63 & 4,85 \\
\hline
\end{tabular}

Based on the results of descriptive statistics, it can be seen that the four research variables, namely the performance accountability of government agencies (Y), the effectiveness of the accounting information system (X1), compliance with legislation (X2), and organizational commitment (X3) show an average value the average is greater than the standard deviation value. This indicates that the four research variables have a more stable level of data distribution. It can also be seen from the difference in the value of the minimum and maximum values of the four variables that have the distance (range) is not too far away.

\section{Research Instrument Testing Results}

a. Based on the results of the validity test, it shows that the correlation coefficient obtained from each item of the variable item performance accountability of government agencies (Y), the effectiveness of the accounting information system (X1), Compliance with Laws (X2), and organizational commitment (X3) all of them are above the critical value of the product moment correlation (correlation coefficient $>0,291$ ) so that the questionnaire used can be declared valid. 


\section{International Journal of Business Management and Economic Review}

Vol. 4, No. 06; 2021

ISSN: 2581-4664

b. Based on the p engujian reliability in mind that each instrument in this study reliable (reliably) because the value Cronb ach's Alpha greater than 0,6 . So it can be concluded that the questionnaire used as a measurement tool in this study is feasible to use (reliable).

\section{Classical Assumption Testing Results}

Based on the histogram graph, it is known that the observation data is normally distributed where the curve is normal. While the P-Plot graph is known that the points move in the direction of the linear line, so it can be concluded that the research regression model is linear.

Based on the figure tolerance of variable effectiveness of accounting information systems (X1), compliance with laws (X2), and organizational commitment $(\mathrm{X} 3)>0,10$, which means that no multikoline a rity between the independent variables. Meanwhile, the VIF value calculation results also showed that none of the independent variables that have a VIF value of more than 10. Thus, it can be concluded that in this study the regression model did not happen multikoline a rity between the independent variables.

From the graph scatterplot is known that there is no particular pattern in the chart, therefore it can be concluded that the regression model in this study is homoskedastisitas or not happen heteroskedastisitas.

\section{Regression Testing Results}

The results of testing the research regression can be seen in Table 2 .

\section{Table 2 Research Regression Testing Results}

\begin{tabular}{|c|c|c|c|c|}
\hline No. & Variable Name & $\begin{array}{c}\text { Regression } \\
\text { Coefficient } \\
(\beta)\end{array}$ & Provisions & Conclusion \\
\hline 1 & $\begin{array}{c}\text { Effectiveness of } \\
\text { Accounting Information } \\
\text { Systems }\left(\mathrm{X}_{1}\right)\end{array}$ & 0,206 & $\beta \neq 0$ & Take effect \\
\hline 2 & $\begin{array}{c}\text { Compliance with Laws } \\
\left(\mathrm{X}_{2}\right)\end{array}$ & 0,200 & $\beta \neq 0$ & Take effect \\
\hline 3 & $\begin{array}{c}\text { Organizational } \\
\text { Commitment }\left(\mathrm{X}_{3}\right)\end{array}$ & 0,228 & $\beta \neq 0$ & Take effect \\
\hline
\end{tabular}

Based on the results of the regression tests, the multiple linear regression equation is obtained as follows:

\section{Discussion}

$$
\mathrm{APGI}=1,708+0,206 \mathrm{EAIS}+0,200 \mathrm{CL}+0,2280 \mathrm{C}+\varepsilon
$$

The Effect of the Effectiveness of the Accounting Information System on thePerformance Accountability of Government Agencies

The results of this research show that the effectiveness of the accounting information system has an effect on the accountability of the performance of government agencies. The regression 


\section{International Journal of Business Management and Economic Review}

Vol. 4, No. 06; 2021

ISSN: 2581-4664

coefficient $(\beta 1)$ obtained is 0,206 , indicating that each increase in the effectiveness of the accounting information system by 1 interval scale unit will be followed by an increase in the performance accountability of government agencies by 0,206 interval scale units. Obtained a positive influence on the effectiveness of accounting information systems on the performance accountability of government agencies. This means that if the accounting information system is implemented effectively in the SKPK of Aceh Singkil Regency, it will increase the accountability of the performance of the local government agency.

The results of this study are in accordance with the theory put forward by Mardiasmo (2006) which states that the application of the Accounting Information System (SIA) based on Government Accounting Standards (SAP) is aimed at increasing the accountability and reliability of government financial managers through the preparation and development of SAP. The AIS is also an effective tool for creating public accountability.

Currently, the accounting information system used in the SKPK Aceh Singkil Regency refers to PP No. 58 of 2005 and Permendagri No. 13 of 2006 and Permendagri No. 59 of 2007. This system is based on a computer network, which is

able to connect and be able to handle data consolidation between SKPD (Regional Work Units) and SKPKD (Regional Financial Management Work Units), so that data in the Regional Government can be properly integrated. Accounting Information System is an accounting system based relational database with a pattern database is centralized (centralized single database) that can be accessed by all units. Therefore, the implementation of SIA in organizations is expected to increase the accountability and reliability of government financial managers through the preparation and development of SAP and other applicable regulations.

The results of this study are in accordance with the results of Ijeoma's (2014) research which shows that the application of the International Public Sector Accounting Standard (IPSAS) can facilitate internal control over financial reports so that it has a positive effect on the accountability of government performance. In addition, the results of this study are also consistent with the results of research conducted by Zulfiandri (2017), Syafariani and Feryani (2014), and Darwanis and Chairunnisa (2013) which also provide results that accounting information systems affect the performance accountability of government agencies in Nigeria. This means that a properly implemented accounting information system will create performance accountability for government agencies.

\section{The Influence of Compliance with laws on the Performance Accountability of Government Agencies}

The results of the research show that compliance with laws affects the accountability of the performance of government agencies. The regression coefficient $(\beta 2)$ obtained is 0,200 indicating that every increase in compliance with legislation by

1 one interval scale will be followed by an increase in the performance accountability of government agencies by 0,200 interval scale units. Obtained a positive effect of compliance with legislation on the accountability of the performance of government agencies. This means that if all SKPK obey the prevailing laws and regulations in Aceh Singkil Regency, it will increase the accountability of the performance of the local government agency. 


\section{International Journal of Business Management and Economic Review}

Vol. 4, No. 06; 2021

ISSN: 2581-4664

The laws and regulations in force in Aceh Singkil Regency regarding agency accountability refer to Government Regulation Number 8 of 2006 concerning Financial Reporting and Performance of Government Agencies; Presidential Regulation Number 29 of 2014 concerning the Performance Accountability System of Government Agencies; Regulation of the Minister for Administrative Reform and Bureaucratic Reform Number 53 of 2014 concerning Technical Guidelines for Performance Agreements, Performance Reporting, and Procedures for Reviewing Performance Reports of Government Agencies; and Regulation of the Minister for Administrative Reform and Bureaucratic Reform Number 12 of 2015 concerning Guidelines for Evaluation of the Implementation of the Performance Accountability System for Government Agencies.

The results of this study are in accordance with the results of research conducted by It is in accordance with the results of research by Irawati and Agesta (2019), Riantiarno and Azlina (20110 Putri (2015) which prove that compliance with

laws affects the accountability of the performance of government agencies. This is because the higher the compliance with laws and regulations by the employees of an agency at work, the higher the accountability for the performance of government agencies.

\section{The Effect of Organizational Commitment on the Performance Accountability of Government Agencies}

The results showed that organizational commitment has an effect on the performance accountability of government agencies. The regression coefficient ( $\beta 3$ ) obtained is 0,228 , indicating that every increase in organizational commitment by 1 interval scale unit will be followed by an increase in the performance accountability of government agencies by 0,228 in the interval scale unit. Obtained the positive influence of organizational commitment on the performance accountability of government agencies. This means that if all SKPKs have a strong commitment, it will increase the accountability of the performance of these local government agencies.

The results of this study are in accordance with the explanation of Darma (2004) which states that organizational commitment can be a psychological aid in running the organization to achieve the expected goals. This is in accordance with Anurti's statement (2913) which states that with high commitment within the organization members will foster the will to work and strive to achieve goals in accordance with existing rules for the achievement of goals and better organizational performance.

The results of this study are consistent with the results of research conducted by Wardhana, Rasmini and Astika (2015), Friska (2015), and Zeyn (2011) which also provide evidence that organizational commitment has a positive influence on public accountability. This condition shows that the better the organizational commitment, the better the success of public accountability by a government agency.

\section{CONCLUSIONS AND RECOMMENDATIONS}

\section{Conclusions}

The effectiveness of the accounting information system, compliance with law and organizational commitment both have a sjointly and separately influenced the accountability performance of government institutions at SKPK Aceh Singkil Regency. 


\section{International Journal of Business Management and Economic Review}

Vol. 4, No. 06; 2021

ISSN: 2581-4664

\section{Recomendations}

1. Continue to improve the effectiveness of accounting information systems to provide for personnel training and supervision of financial management in order to realize the accountability of agencies.

2. The Regency also needs to provide a comprehensive understanding regarding applicable regulation as a reference in realizing agency accountability for the apparatus and all relevant structural managements in the SKPK

3. The agency of Aceh Singkil District also needs to increase organizational commitment to realizing agency accountability by providing rewards for SKPKs that have good accountability and punishment for those who have bad accountability.

\section{REFERENCES}

Alimbudiono, R. S. \& F. A. Andono. (2004). Kesiapan Sumber Daya Manusia Sub Bagian Akuntansi Pemerintah Daerah dan Kaitannya dengan Pertanggungjawaban Keuangan Daerah kepada Masyarakat: Renungan Bagi Akuntan Pendidik. Jurnal Akuntansi dan Keuangan Sektor Publik, 5 (2), 18-30. Bastian, I. (2010). Akuntansi Sektor Publik: Suatu Pengantar Edisi Ketiga. Jakarta:

Erlangga.

Chong, V. K. \& K. M. Chong. (2002). Budget Goal Commitment and Informational Effect of Budget Participation on Performance. A Structural Equation Modeling Approach. Behavioral Research In Accounting. 14, 65-86.

Dharma, S. (2002). Paradigma Baru Manajemen Sumber Daya Manusia.

Yogyakarta: Amara Books.

Fawzi, A. (2012). Pengaruh Pengawasan Intern dan Sistem Informasi Akuntansi terhadap Kinerja Pemerintahan Kota Tasikmalaya. Skripsi. Program Studi Akuntansi Universitas Siliwangi.

Halim, A. (2008). Akuntansi Sektor Publik: Akunatnsi Keuangan Daerah. Jakarta: Salemba Empat.

Ijeoma, N. B. (2014). The Impact of International Public Sector Accounting Standard (IPSAS) on Reliability, Credibility and Integrity of Financial Reporting in State Government Administration in Nigeria. International Journal of Technology Enhancements and Emerging Engneering Research, 2, (3).

Kurniawan, M. (2013). Pengaruh Komitmen Organisasi, Budaya Organisasi, dan Kepuasan Kerja terhadap Kinerja Organisasi Publik. Artikel Ilmiah. Program Studi Akuntansi Fakultas Ekonomi Universitas Negeri Padang.

Mardiasmo. (2006). Akuntansi Sektor Publik. Yogyakarta: Andi OFFSET.

Permana, I. (2012). Pengaruh Penerapan Standar Akuntansi Pemerintahan terhadap Kualitas Laporan Keuangan Pemerintah Daerah dan Implikasinya pada Akuntabilitas Survei pada Dinas Kota Bandung. Skripsi. Bandung: Universitas Komputer Indonesia.

Revika, R. (2015). Pengaruh Kualitas Sumber Daya Manusia, Komitmen Organisasi, Komunikasi Organisasi, dan Partisipasi Anggaran terhadap Kinerja Satuan Kerja Perangkat Daerah (SKPD) di Kota Payakumbuh. JOM FEKON, 2 (1), 1 -

15. 
International Journal of Business Management and Economic Review

Vol. 4, No. 06; 2021

ISSN: 2581-4664

Robbins, S. P. (1998). Organization Behavior, Concepts, Controversies, Application. Seventh Edition. Jakarta: Englewood Cliffs dan Prenhallindo.

Salbiah \& R. Rizky. (2012). Pengaruh Evaluasi Anggaran Terhadap Kinerja Satuan Kerja Perangkat Daerah (SKPD) Pemerintah Provinsi Sumatera Utara. Jurnal Ekonom, 15 (2), 42-52.

Suci, D. J. (2013). Pengaruh Kualitas Sumber Daya Manusia, Komitmen Organisasi, dan Komunikasi Organisasi terhadap Kinerja Satuan Kerja Perangkat Daerah. Jurnal Akuntansi. Fakultas Ekonomi. Universitas Negeri Padang. 